\title{
RELATIONSHIP BANKING: A MULTINATIONAL BANK'S APPLICATION OF RELATIONSHIP MARKETING
}

\author{
Sanjay S. Mehta \\ Sam Houston State University \\ Huntsville, TX \\ Balasundram Maniam \\ Sam Houston State University \\ Huntsville, TX \\ Subhash C. Mehta \\ National University of Singapore \\ Singapore
}

\begin{abstract}
We are witnessing a paradigm shift in the focus of marketing from one that has been transaction-oriented to one that builds a value-enhancing relationship with the customer. One of the earliest industries to jump onto the bandwagon of "relationship marketing" has been the banking industry. This paper investigates a multinational bank's use of relationship marketing by using McKinsey \& Co. 's Seven-S framework. The study identifies internal marketing, service quality, human resource system, information technology, and the role of the account manager as key factors in implementing a relationship marketing strategy.
\end{abstract}

\section{Introduction}

While exchange is still sited as the ontology of the marketing disciple (Houston \& Gassenheimer, 1987), we are witnessing a paradigm shift in the conceptualization and measurement of marketing transactions; this shift has been labeled relationship marketing. "Relationship marketing refers to all marketing activities directed towards establishing, developing, and maintaining successful relationship exchanges" (Morgan \& Hunt, 1994, p. 22). In explaining the relationship marketing concept in a business-to-business context, Kotler (1997, p.8) contends that, "Smart marketers try to build up long-term, trusting, 'win-win' relationships with customers .... That is accomplished by promising and delivering high quality, good service, and fair prices to the other party over time. It is accomplished by strengthening the economic, technical, and social ties between members of the two organizations." The relationship concept, when properly implemented, cuts down on transaction costs and time, thus providing organizations with a critical competitive edge (Kotler, 1997; Turnbull, 1983). The rela- 
tionship marketing concept has tremendous potential when developed and implemented in the banking context (Thurman, 1992), where the emphasis is on selling "repeat" services (Lovelock, 1996).

Banks realized early on that marketing is more than just acquiring new customers; it also involves retaining existing-customers and selling them a wider assortment of products (i.e., goods and services). Today's competitive banking environment demands an ever increasing consumer responsiveness. With deregulation, globalization, and automation, corporate customers now have a wide array of choices in banking services. These environmental changes, coupled with the saturated demand for banking products, have made most multinational banks marketing-oriented. Marketing orientation is a philosophy that assumes that a sale depends on a customer's decision to purchase a product rather than on aggressive selling (Lamb, Hair, \& McDaniel, 1998).

While much attention has been paid to the effect of deregulation, technological innovations, and competition in the banking industry, little consideration has been given to the bank-customer relationship and on how to enhance that relationship. For instance, Vikkula (1992) studied the effects of deregulation on Finnish Banks and analyzed the competitiveness of these banks in the 1900s. He concluded that banks' competitive position will be threatened by stringent regulations, competition from foreign banks, and alternative products offered by companies outside the banking sector. He asserted that Finnish banks can improve their competitiveness by concentrating on bank-customer relationships. Several scholars in the past (Donnelly, Berry, \& Thompson, 1985; Eccles \& Crane, 1988; Moriarity, Kimball \& Gay, 1983) have discussed long-term relationships between banks and customers in connection with relationship marketing; appropriately labeled relationship banking. The relationship banking approach is a contrast to the traditional approach of a bank as an "order-taker." Watson (1996) recommended that banks must allocate resources to developing relationship banking, with an account manager responsible for each customer. Similarly, Turnbull (1982a and 1982b) and Turnbull and Gibbs (1986) emphasized the need for relationship banking as a viable long-term strategy. To effectively implement relationship banking, all the processes (e.g., people, information) must be in place (Moriarity, Kimball, \& Gay, 1983). Keltner (1995) stressed this point in his cross-boundary study when he compared U.S. and German banks. He found that U.S.based banks were shifting away from relationship banking and encouraged customers to turn to other financial institutions to meet their banking needs. In contrast, German banks were being able to maintain a stable share of that country's financial services market. German banks were investing in human resources and organizational capabilities necessary to pursue strategies based on relationship banking. He also pointed out that U.S.-based banks can realize the benefits of relationship banking if they commit themselves to creating stronger internal labor markets and reducing employee turnover. Keltner (1995) 
concluded by stating that U.S.-based banks can go a long way towards rebuilding their capacity from relationship banking by simply emulating German banks' commitment to internally developed human capital.

There have been several studies directed towards the management of relationships between buyers and sellers (Anderson \& Narus, 1984; Crosby, Evan, \& Cowles, 1990; Donnelly, Berry, \& Thompson, 1985; Boyle, Dwyer, Robicheaux, \& Simpson, 1992; Dabholkar, Johnston, \& Cathey, 1994). Using data from the banking industry, Perrien, Filiatrault, and Ricard (1993) extended these studies by analyzing factors necessary for implementing relationship banking. They concluded that the implementation of a relationship marketing strategy impacted major corporate decisions (e.g., human resources' management, organizational structure).

\section{Purpose}

In this study, we offer an international perspective of relationship banking. Extensive literature review revealed that no previous study has looked at the consequence of a multinational bank's implementation of a relationship marketing strategy. Specifically, the main objective of this paper is to investigate a multinational bank's application of relationship marketing (i.e., relationship banking), using McKinsey's Seven-S framework (Peters \& Waterman, 1982; Waterman, Peters, \& Phillips, 1991) (see Figure 1). The Seven-S framework encompasses the seven elements common to successful organizations: shared values, style, strategy, structure, staff, skills, and systems.

Depth interviews were conducted with a sample of forty-two (of the fortyfive presently employed) Account Relationship Managers from a large multinational bank in Singapore (see Appendix for a copy of the questionnaire). While other qualitative (e.g., protocol analysis, projective techniques) and quantitative (e.g., a mail survey) research techniques were considered, the research design (e.g., population size, sampling and non-sampling error) warranted that depth interviews would be the most appropriate methodology (Alreck \& Settle, 1995). This bank, which we will term DELTA Bank, has more than one hundred years of international trade involvement. It is widely believed that DELTA Bank is the best finance institution in Asia. DELTA Bank has a worldwide network of more than 700 offices in 50 countries. With more than 20 branches within Singapore, DELTA Bank is able to provide a wide range of services (e.g., stockbroking services, currency and commodity trading, corporate and private banking services, investments and fund management). We believe that perceptions and opinions of DELTA Bank managers bring into focus the interrelationship between the McKinsey Seven-S framework and relationship marketing strategy within the banking sector. 
Figure 1

\section{McKinsey's 7-S Framework}

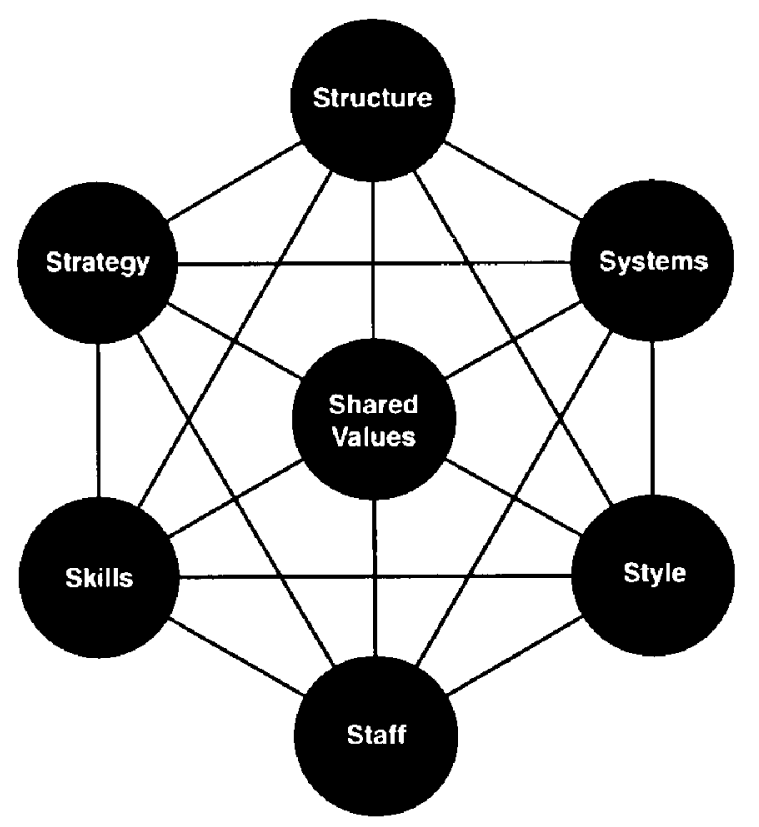

Source: Peters, T. J. \& Waterman, Jr., R. H. (1992), In search of excellence: Lessons from America's best-run companies

\section{Seven-S Framework as Applied to Delta Bank}

McKinsey's Seven-S framework was developed and proposed by Peters and Waterman (1982) and championed by Waterman, Peters, and Phillips (1991) to explain organizational change. The traditional model of the organization is that strategy is the starting point in implementing any change and that structure and system flow from that (Kotler, 1997). The central idea behind McKinsey's Seven$S$ framework is that organizational effectiveness stems from the interaction of the seven factors: strategy, shared values, style, system, structure, skills, and staff (see Figure 1). McKinsey \& Co.'s research shows that top performing companies place emphasis on four additional elements (besides strategy, structure, and system). Christopher, Payne, and Ballantyne (1991) suggest that the Seven-S framework is ideally suited for analyzing the feasibility of planned organizational change. They lay special emphasis on the application of this framework for evaluating a firm's relationship marketing strategy.

\section{Strategy}

Relationship banking is driven by the perceived impetus to enter into a longterm relationship (as opposed to a one-time transaction) with customers. The benefits to organizations arise primarily due to cross-selling of products (especially 
fee-based income products), thereby increasing the level of penetration. Other resulting spin-offs from the relationship marketing strategy are higher margins and the conception of product development skills. The economics of retaining a customer vis-a-vis gaining a new one and the resulting word-of-mouth publicity are additional incentives.

Relationship banking helps the customers as well. They benefit from ready access to credit at relatively lower costs and risk. More important, the customer gets privileged personalized service and customized offerings. In order for relationship banking to succeed, it needs to be integrated with all facets of the organization. Success is further enhanced through niche marketing where the bank identifies one key segment on which to focus its energy. Accordingly, DELTA Bank identified "trade financing" as its niche. The strategy is to mold this core service by customizing it to the needs of individual clients. Having impressed upon the customer the bank's ability to solve special problems, the Account Relationship Managers gains credibility. This serves to engender future purchases and the crossselling of the bank's product line.

\section{Shared Values}

Shared values represent the "glue" responsible for bonding together the entire organization. In any relation exchange, solidarity is necessary for bonding a longterm relationship (Mehta, 1999). DELTA Bank's managers unanimously agreed that in order for relationship banking to succeed, organizations should place a premium on customer service. The organizational ethos should reflect the realization that satisfaction of customers' needs and wants are the very reason for the organization's existence (referred to as the marketing concept).

Account Relationship Managers concur that for relationship banking to succeed, the responsibility for customer service has to be equally accepted by both the marketing and the non-marketing personnel. The extent of conflict that exists between the Account Relationship Managers and the operations unit suggests that developing long-term relationships with clients may be a high priority for the Account Relationship Managers.

Our interactions with Account Relationship Managers suggest that in order for relationship banking to become a part of a bank's shared values, top management needs to commit itself to service excellence. DELTA Bank's managers believe that service excellence results from constant on-going training of all employees. Communicating the firm's commitment to relationship marketing to employees at all levels goes a long way towards relationship banking. Also evident from our interactions with DELTA Bank's Account Relationship Managers, was the need on the part of top management to exercise the same care and empathy towards the bank's employees as one would expect in the bank's dealings with customers. It is in this domain that internal marketing has a major role to play. Internal marketing is ". . . the task of successfully hiring, training, and motivating able employees to serve the customers well" (Kotler, 1997, p. 20). Internal marketing dictates 
acceptance of a firm's employees as internal customers. Chaston (1995) suggested that in order for a bank to do well with its external customers, they must first practice internal marketing. Internal marketing is a philosophy for managing the organization's human resources based on a marketing perspective (Kotler, 1997; Lamb, Hair, \& McDaniel, 1998). Some activities necessary for implementing internal marketing include (Berry \& Parsuraman, 1991): giving employees more freedom to make decisions, measuring and rewarding good performance, knowing employees' needs, stressing teamwork, and offering a vision. How the employees deal with customers is largely predicated by the employees' perceptions of how well they are treated by management.

\section{Style}

The style of management is demonstrated by the actions of top managers. DELTA Bank's managers felt that the management style of their organization has been historically very conservative. Perpetuation of a hierarchical structure has resulted in an ossified management style that stifles decision making at the point of contact. It also inhibits an open flow of communication of information along the ranks. Account Relationship Managers believe that such a management style gets in the way of good customer service.

A related issue is the delegation of authority. In the banking context, empowerment of the frontline marketer is always difficult. But developing credibility and trust with the customer necessitates the ability on the part of the Account Relationship Manager to make quick decisions. Research has shown that trust among exchange partners is necessary for the implementation of a relationship marketing strategy (Morgan \& Hunt, 1994). Empowerment of the Account Relationship Manager, as a crucial component of management style, will thus positively impact relationship banking.

\section{Systems}

The main problems highlighted by DELTA Bank's Account Relationship Managers in relation to systems revolved around internal coordination. These include resolving conflicts with operating units, the evaluation process of employees, and recruitment of Account Relationship Managers. While conflict may be an integral part of any exchange relationship, it is the resolution of the conflict that is important in a relationship marketing strategy (Mehta, 1999).

Appropriate selection systems for Account Relationship Managers will significantly impact their level of performance along the relationship marketing dimension. DELTA Bank implemented the Account Relationship Manager concept in 1987. Prior to 1987, account managers were not allocated specific accounts. Presently a typical Account Relationship Manager handles up to 40 accounts. His/her job was to be market-oriented, to keep existing customers happy, to further cement the relationship, and to seek out new customers. Operationally, the Account Relationship Manager had to be involved in the relationship-build- 
ing process at all stages: initiation, cultivation, and preservation (Mehta, 1998). Therefore, identifying and prospecting a new client, performing credit appraisal, undertaking the documentation, monitoring the loan, and recovering the loan, were necessary for Account Relationship Managers.

Keeping in mind the boundary-spanning role of the Account Relationship Manager, it is necessary to recruit Account Relationship Managers who possess high interactive skills and abilities, a belief in customer care, and knowledge of the bank's products and of the competitive environment. It was felt that lateral movement from operations to corporate banking would help the Account Relationship Manager to gain both the knowledge and the appreciation of operations. Generally, the rotation of non-marketing staff into customer contact positions serves to improve marketing orientation of the organization.

The employees' appraisal processes currently in vogue at DELTA seem to be disproportionately bottom-line driven. In addition to operation-based efficiency measures (e.g., an Account Relationship Manager's account profitability), soft qualitative assessment needs to be incorporated in the appraisal structure. Such assessment might include "saving" a dissatisfied customer, making correct credit evaluations in not lending to a prospective customer, number of customer calls made, and the response time for customer enquiry.

DELTA Bank's managers viewed continuous training as invaluable to successful relationship marketing. Their perceptions are consistent with Heskett's (1987) who said that, ". . . effective service requires people who understand the idea." Employees need to view their job from a holistic perspective. This can best be achieved by training programs that emphasize the interrelationships between the various activities of an organization. Training should also provide a common forum for Account Relationship Managers and the operations staff, thereby providing opportunities for the cross-fertilization of ideas and enhancing mutual understanding.

The systems aspect of McKinsey's Seven-S framework also encompasses information systems. DELTA Bank's managers felt the pressing need to develop a user-friendly reporting system which enables the Account Relationship Managers to compute the viability of an account. DELTA Bank already had a management information system and a decision support system to gather competitive and customer intelligence, but Account Relationship Managers felt the need for further refinement in these systems as well.

\section{Structure}

It was discovered that DELTA's existing organizational structure is flawed and that the structure breeds and encourages conflicts between the Account Relationship Managers and the operational staff. The structure needs to be modified such that coordination between operations and the corporate banking staff can be facilitated. One possible solution to address the structure bottlenecks is rotation between operations and the relationship management staff. Another method is to 
have account managers within product specialist areas. A third solution to resolve structure-based inefficiencies is to have a common chief for both operations and corporate banking.

For example, in the existing setup within the corporate banking division, the Account Relationship Manager is far removed from the approval authority. To facilitate a more rapid decision making process, a flatter structure may be more conducive to decision making. Therefore, the Account Relationship Manager will report directly to the individual approving the credit proposals. Allocation of accounts to Account Relationship Managers could be done on the basis of industry (Kale \& Sudharshan, 1987). This would promote specialization in industry financing needs and make it easier for the account managers to better identify with their clients. In dealing with multinational corporations, however, Account Relationship Manager allocation based on clients' markets, as is presently done, seems advisable.

The size of the portfolio handled by each Account Relationship Manager has implications on the quality of relationships. It is crucial that the portfolios are limited to 40 to 50 medium-sized clients or up to 100 small clients. The greater the client homogeneity in the portfolio, the easier it will be for the Account Relationship Manager to understand and appreciate client needs.

\section{Skills}

The skills of the Account Relationship Manager are crucial to the success of the relationship marketing strategy. The Account Relationship Manager's boundary-spanning function between the bank and the client makes relationship banking happen. The Account Relationship Manager thus needs knowledge of the bank's goods and services, knowledge of the client and its industry, and knowledge of the competitive environment. Armed with knowledge of the bank's offerings, the Account Relationship Manager can tailor products to the needs of specific clients. Implicit in client interactions are the client's trust and confidence in the Account Relationship Manager (Morgan \& Hunt, 1994).

DELTA Bank's Account Relationship Managers felt that good interaction skills were of paramount importance for a relationship manager. Product knowledge and technical skills were also deemed important, but it was widely felt that these could be acquired with relative ease.

\section{Staff}

At the very basic level, the Account Relationship Manager is supported by the corporate Account Relationship Manager team. The staff assistant provides backup in the Account Relationship Manager's absence and also helps with documentation and data gathering. The Credit Management Department provides support by ensuring that credit evaluations are in line with the bank's standards. The Security Documentation Unit ensures that once a client facility is approved, the appropriate documentation is prepared. Prior to actual disbursement, the Account Relationship Manager had to confirm adequacy of the documentation. 


\section{Conclusion}

Research in service industries has shown that overall job satisfaction on the part of employees is positively correlated to their level of customer orientation (Hoffman \& Ingram, 1992). The DELTA Bank study confirms a similar relationship in the banking context. This underscores the need for a strong internal marketing program on the part of bank management. Management needs to constantly monitor the motivation and morale of the bank's employees. In the absence of a motivated workforce, relationship marketing will not yield positive results.

Periodic measurement of the level of service quality delivered will also impact the success of relationship banking. Measuring service quality is important for service organizations with many intangible factors. Researchers have identified a positive association between service quality and customer satisfaction (Fitzsimmons and Fitzsimmons, 1994). DELTA, like most banks, does not have an effective instrument with which to assess the quality of its services. Instruments such as SERVQUAL (a 22 -item scale that measures five dimensions of service quality) could be of immense benefit to banks desirous of practicing relationship marketing (Parsuraman, Zeithaml, \& Berry, 1985; Parsuraman, Zeithaml, \& Berry, 1988).

The human resource systems of a bank are also a crucial determinant of its effectiveness in relationship banking. The bank needs to recruit and train people such that its customer orientation becomes ingrained in every employee. Performance appraisal measures should be broadened to incorporate an employee's commitment to the customers and his/her boundary performance with the clients.

Information technology can significantly add to the level of relationship banking. For example, on-line access to account profitability would help Account Relationship Managers with their lending decisions. Technology can be harnessed to build a management information system that provides meaningful and actionable data on current and potential customers. Such a system would make client prospecting and rapport building easier for the Account Relationship Managers.

The bank needs to appreciate the key role played by the Account Relationship Manager in relationship banking. The Account Relationship Manager is a strategic resource that needs to be employed with flair and distinctiveness. In order to enable the Account Relationship Manager to perform his/her role better, a bank needs to structure the job such that a reasonable amount of time is available for client interaction. Relieving the Account Relationship Manager of some of the documentation and other operations formalities will ensure proper attention to building client rapport. Also, the Account Relationship Manager needs to be given greater authority and easier access to the operations and support staff. Having exclusive product specialists serving the Account Relationship Manager may be one effective but expensive approach to better performance.

This paper has been exploratory in its orientation. The key limitation of this study is the exploration of relationship marketing strategy using just one bank 
(i.e., a case study). Future research should be based on empirical data using several banks across geographic boundaries (i.e., descriptive study). This will help researchers in uncovering the commonality in perceptions of respondents from various organizations. Another limitation of the current study is that it assesses only the seller's perspective. Relationship marketing should ideally be investigated using data from both sides of the management-customer dyad (Mehta, 1998). These limitations notwithstanding, this study does bring into focus key aspects of relationship banking as explained by McKinsey's Seven-S framework. Based on the DELTA Bank study, five key success factors for relationship banking were identified: internal marketing, service quality, human resource systems, information technology, and the role of the Account Relationship Manager.

The Account Relationship Manager has to have a great deal of day-to-day interactions with officers in the various support departments. Many times, the interests of the various individuals diverge. For instance, while client interest may be predominant for the Account Relationship Manager, margins may be the driving motivation for the bank. Such inevitable conflicts between the various staff can be effectively handled by imbibing a customer focus in every staff member. As one Account Relationship Manager succinctly puts it, "undoubtedly, Account Relationship Manager has to be market driven, but there has to be a cascading of this culture to the support staff. After all, a relationship cannot be developed solely on the basis of an Account Relationship Manager."

With increasing competition in the banking sector, relationship marketing will continue to grow in prominence. Its success, however, is contingent on the level of consistency between the various factors discussed under the Seven-S framework.

\section{References}

Alreck, P. L., \& Settle, R. B. (1995). The survey research handbook, (2nd ed). Homewood, IL: Richard D. Irwin, Inc.

Anderson, J. C., \& Narus, J. A. (1984). A model of distributor's perspective of distributor-manufacturer working relationships. Journal of Marketing. 54 (January), 42-58.

Berry, L. L., \& Parsuraman, A. (1991). Marketing services. New York: Free Press.

Boyle, B., Dwyer, R. F., Robicheaux, R. A., \& Simpson, J. T. (1992). Influence strategies in marketing channels: Measures and use in different relationship structures. Journal of Marketing Research, 29 (4), 462-473.

Chaston, I. (1993). Delivering customer satisfaction within the SME (small and medium size enterprise) client-banker relationship. Service Industries Journal, 13 (1), 98111. 
Christopher, M., Payne, A., \& Ballantyne, D. (1994). Relationship marketing: Bringing quality customer service, and marketing together, (2nd ed). Oxford: Butterworth Heinemarln.

Crosby, L. A., Evans, K. R., \& Cowles, D. (1990). Relationship selling in services selling: An interpersonal influence perspective. Journal of Marketing, 54 (July), 68-81.

Dabholkar, P. A., Johnston, W. J., \& Cathey, A. S. (1994). The dynamics of long term business to business exchange relationships. Journal of Academy of Marketing Science, 22 (Spring), 130-145.

Donnelly, J. H., Berry, L. L., \& Thompson, T. W. (1985). Marketing financial services A strategic vision. Dow Jones-Irwin, Homewood, IL.

Eccles, R. G., \& Crane, D. B. (1988). Doing deals - Investment banks at work. Harvard Business School Press. Boston

Fitzsimmons, J.A., \& Fitzsimmons, M. J. (1994). Service management for competitive advantage. McGraw Hill, New York

Heskett, J. (1987). Lessons in the service sector. Harvard Business Review, 65 (March/ April), 118-126.

Hoffman, D., \& Ingram, T. (1992). Service provider job satisfaction and customer oriented performance. Journal of Service Marketing, 6 (2), 68-77.

Houston, F., \& Gassenheimer, J. B. (1987). Marketing and exchange, Journal of Marketing. 51 (October), 3-18.

Kale, S. H., \& Sudharshan, D. (1987). A strategic approach to international segmentation. International Marketing Review, Summer, 60-70.

Keltner, B. (1995). Relationship banking and competitive advantage: Evidence from U.S. and Germany. California Management Review, 37 (4), 45-72.

Kotler, P. (1997). Marketing management. 9th ed., Englewood Cliffs, NJ: Prentice Hall.

Lamb, C. W. Jr., Hair, J. F., \&. McDaniel, C. (1998). Marketing. South-Western College Publishing, 4th ed.

Lovelock, C. H. (1996). Services marketing. Englewood Cliffs, NJ: Prentice Hall.

Mehta, S. S. (1999). Continuity expectation in vertical marketing systems: A dyadic perspective of domestic and international franchising. unpublished dissertation, University of North Texas. 
Moriarity, R. T., Kimball, R. C., \& Gay, J. H. (1983). The management of corporate banking relationships. Sloan Management Review, Spring.

Morgan, R. M., \& Hunt, S. D. (1994). The commitment-trust theory of relationship marketing. Journal of Marketing. 58 (July), 20-38.

Parsuraman, A., Zeithaml, V., \& Berry, L. (1985). A conceptual model of service quality and implications for future research. Journal of Marketing, (Fall), 41-50.

Parsuraman, A., Zeithaml, V., \& Berry, L. (1988). SERVQUAL: A multiple-item scale for measuring consumer perception of service quality. Lournal of Retailing. 64 (1), $12-40$.

Perrien, P., Filiatrault, A., \& Ricard, T. (1993). The implementation of relationship marketing in commercial banking. Industrial Marketing Management, 22, 141-148.

Peters, T. J., \& Waterman, R. H. Jr. (1982). In search of excellence: Lessons from America”s best-run companies. Warner books

Thurman, C. G. (1992). Corporate banking: Services and relationships. International Joumal of Marketing, 10 (2), 10-16.

Turnbull, P. W. (1982a). The purchasing of international financial services by medium and large sized UK companies with European subsidiaries. in Tumbull, P. W. and Lewis, B. R. (Eds). The marketing of bank services. MCB Publications, Bradford, 122-132.

(1982b). The use of foreign banks by British companies. in Turnbull, P. W. and Lewis, B. R. (Eds). The marketing of bank services. MCB Publications, Bradford, 133-145.

(1983). Corporate attitudes towards bank services. International Joumal of Bank Marketing 1 (1), 53-65.

Turnbull, P., \& Gibbs, M. L. (1986). Marketing bank services to corporate customers: The corporate attitudes towards bank services. International Journal of Bank Marketing. 5 (1), 19-26.

Vikkula, K. (1992). The competitiveness of Finnish banks in the 1990s. Kansallis-OsakePankki Economic Review, (1), 13-24.

Waterman, R., Peters, T., \& Phillips, J. (1991). The seven-s framework. The strategy process: concepts, contexts, cases. H. Mintzberg and J. Quinn (eds), Englewood Cliffs, NJ: Prentice Hall.

Watson, I. (1986). Managing the relationship with corporate customers. International Journal of Bank Marketing, 4 (1), 19-34. 


\section{Appendix \\ Questionnaire for the Depth Interview}

1. What is relationship banking as your bank sees it? Is it a part of the overall strategy of the bank?

2. How do you segment the customer base? How does the bank benefit from the concept?

3. What does the customer stand to gain from such a relationship? Do you believe it is appropriate for all your customers?

4. How do you decide whether a particular customer is worth being treated on a relationship basis?

5. What is the product strategy (i.e., to offer a full range of standardized products or customized products depending on the needs of the customer or a combination of both)?

6. How do you see the role of the Account Relationship Manager?

7. What do you believe are the most crucial aspects of the Account Management Strategy?

8. Is it possible to ensure that the benefits offered by your bank are meaningful and are not copied by the competitor?

9. What do you feel is the role of "Internal Marketing" (i.e., a service oriented culture to the success of such a program)?

10. Does your bank measure Service Quality on a on-going basis?

11. What are some of the more typical problems associated with the implementation of the Relationship banking program?

12. How does the Account Relationship Manager fit into the overall organizational structure?

13. What is the basis of the territory allocation? Is there a problem in ensuring strict adherence to the territory? 
14. What according to you is the role of training in the success of a programs such as this one? What training do employees of your bank receive.

15. What kind of incentive plans are operative in your bank?

16. What are the kind of qualities/skills that should be sought for in a good Account Relationship Manager?

17. What kind of internal support do you expect from departments? Do you have any problems in obtaining this kind of support?

18. What do you feel is the future of the relationship management concept? What do you feel are the critical success factors?

Sanjay S. Mehta (M.S., Ph.D., University of North Texas) is currently an Assistant Professor of Marketing at Sam Houston State University. He holds a B.S. in Mathematics and an MBA in Management from Angelo State University. He has presented over 50 papers at regional, national, and international conferences and served as track chair, session chair, discussant, and reviewer at many of these conferences. He has published over 40 articles in various refereed proceedings and journals.

Balasundram Maniam (Ph.D., University of Mississippi) is currently an Assistant Professor of Finance at Sam Houston State University. He holds a B.S. in Computer Science and an MBA in Management from Arkansas State University. He has presented over 55 papers at regional, national, and international conferences. He has published over 40 articles in various refereed proceedings and journals.

Subhash C. Mehta (Ph.D., University of Missouri) is an Associate Professor of Marketing at The National University of Singapore. He has published over 150 articles in various refereed proceedings and journals. In addition, he has authored and co-authored several textbook in marketing. Dr. Mehta has over 30 years of international teaching and consulting experience. 